EXTENDED REPORT

\title{
A family based study shows no association between rheumatoid arthritis and the PADI4 gene in a white French population
}

\author{
L Caponi, E Petit-Teixeira, M Sebbag, F Bongiorni, S Moscato, F Pratesi, C Pierlot, \\ J Osorio, S Chapuy-Regaud, M Guerrin, F Cornelis, G Serre, P Migliorini, for ECRAF
}

See end of article for authors' affiliations

Correspondence to: Dr Paola Migliorini, Clinical Immunology Unit, Department of Internal Medicine, University of Pisa, via Roma 67, I-56126 Pisa, Italy; p.migliorini@med.unipi.it

${ }^{*}$ Members of ECRAF are given at the end of the article

Accepted 12 August 2004 Published Online First 14 October 2004
Background: Autoantibodies to citrullinated proteins (ACPA) are considered a specific marker for rheumatoid arthritis. Peptidylarginine deiminase (PAD) is the enzyme that converts arginyl into citrullyl residues; different isoforms of the enzyme are expressed in mammals. It has been suggested that the PADI4 gene may contribute to genetic susceptibility to rheumatoid arthritis, but conflicting results have been obtained in different populations.

Objective: To test the hypothesis that the PADI4 gene may confer susceptibility to rheumatoid arthritis in a white French population, using powerful and highly reliable family based association tests.

Methods: DNA samples were analysed from 100 families where one member was affected by rheumatoid arthritis and both parents were available for sampling. Five single nucleotide polymorphisms, located within the PADI4 gene and in its close proximity, were genotyped by restriction fragment length polymorphism, and haplotypes were constructed. The analysis involved use of the transmission disequilibrium test and genotype relative risk. ACPA were detected by ELISA on cyclic citrullinated peptides and on human deiminated fibrinogen.

Results: No single SNP or haplotype was associated with the disease, or was preferentially transmitted. No association was found when patients were partitioned according to ACPA positivity.

Conclusions: No PADI4 haplotype is associated with rheumatoid arthritis in a white French population. The role of genes encoding the other PAD isoforms, or modulating tissue expression or enzyme activity, remains to be elucidated.
$\mathrm{R}$ heumatoid arthritis is one of the most common immune mediated diseases, occurring worldwide in about $1 \%$ of the adult population. Its major distinctive feature is chronic, symmetrical, erosive synovitis, with the formation of a highly proliferative and invasive granulation tissue referred to as "pannus." It is a complex disease with poorly understood pathogenesis, but the involvement of both cellular and humoral autoimmune mechanisms has been clearly demonstrated.

Various autoantibodies are present in the serum of rheumatoid patients. Among these are autoantibodies to deiminated or "citrullinated" proteins (anti-citrullinated protein antibodies or ACPA), which are now recognised as being the most disease specific. ${ }^{1-3}$ Their detection is increasingly being used as a diagnostic tool, though the presence of rheumatoid factor (RF) remains the sole serological criterion used in the classification of rheumatoid arthritis. ${ }^{4}$

The ACPA encompass several overlapping autoantibody families, including the so called antikeratin antibodies (AKA) and antiperinuclear factor (APF). AKA and APF have been shown to recognise deiminated forms of filaggrin or its precursor profilaggrin..$^{5-8}$ There is evidence that citrullyl residues in the context of specific amino acid sequences are the epitopes recognised by ACPA. ${ }^{8}$ However, squamous epithelia do not correspond to the sites of rheumatoid inflammation, and (pro)filaggrin is not expressed in articular tissues. ${ }^{8}$ Indeed, in synovial tissues major ACPA targets have emerged that were identified as deiminated forms of the $\alpha$ and $\beta$ chains of fibrin. ${ }^{10}$ On the other hand, ACPA have been shown to be produced by plasmocytes of the rheumatoid pannus and to be concentrated in the rheumatoid synovium. ${ }^{11}$
The simultaneous presence of ACPA and their antigenic targets in the rheumatoid synovium suggests that the interaction of ACPA with deiminated fibrin plays a crucial role in the pathogenesis of rheumatoid arthritis. This hypothesis is supported by the fact that ACPA appear early in the disease course, ${ }^{12-14}$ often before any clinical symptoms, ${ }^{15-18}$ and are associated with the most severe forms of the disease. ${ }^{19-22}$

The enzyme responsible for the conversion of arginyl residues into citrullyl residues-peptidylarginine deiminase (PAD)-has been detected in many mammalian tissues. cDNA cloning analysis has shown the presence of five isoforms in rodents: PAD I, ${ }^{23}{ }^{24} \mathrm{PAD} \mathrm{III}^{25}$ PAD II and PAD IV, ${ }^{24}{ }^{26-28}$ and ePAD, ${ }^{29}$ which was recently provisionally named PAD VI. ${ }^{30}$ Five isoforms of human PAD have also been cloned: PAD I, ${ }^{31}$ PAD II, ${ }^{32}$ PAD III, ${ }^{33}$ PAD V, ${ }^{34}$ which is the enzyme most closely related to rodent PAD IV and was therefore renamed $\mathrm{PAD} I V,{ }^{30}$ and finally, the latest cloned isoform which has tentatively been named PAD VI in order to avoid confusion with human PAD IV/V. ${ }^{35}$ PAD I has been detected in the epidermis, ${ }^{31}$ PAD II in sweat glands, ${ }^{36}$ and PAD III in hair follicles, ${ }^{37}$ while PAD IV has been found in the precursors of macrophages and neutrophils, ${ }^{38}{ }^{39}$ and PAD VI mRNA has

Abbreviations: ACPA, anti-citrullinated protein antibodies; AhFibA, anti-human fibrin(ogen) autoantibodies; CCP, cyclic citrullinated peptides; ECRAF, European Consortium for Rheumatoid Arthritis Families; GRR, genotype relative risk; PAD, peptidylarginine deiminase; $\mathrm{RF}$, rheumatoid factor; RFLP, restriction fragment length polymorphism; SNP, single nucleotide polymorphism; SSCP, single strand conformational polymorphism; TDT, transmission disequilibrium test 
been detected in the ovary, testis, and peripheral blood leucocytes. ${ }^{35}$

The genome-wide linkage study of rheumatoid arthritis sibling pairs conducted in 1998 by the European Consortium for Rheumatoid Arthritis Families (ECRAF) ${ }^{40}$ found evidence of linkage in the 1 p36 locus encompassing all the known PADI genes. More refined analysis has recently confirmed this finding ${ }^{41}$ : microsatellites D1S2644 and D1S478 showed evidence of linkage, suggesting the possible existence of a candidate gene in this region of chromosome 1.

Recently, a case-control association study analysed the single nucleotide polymorphisms (SNPs) located in the PADI genes region in Japanese patients with rheumatoid arthritis. In that study no significant associations were found with SNPs in the genes PADI1, PADI2 and PADI3. On the contrary, the investigators identified a haplotype of the PADI4 gene associated with susceptibility to rheumatoid arthritis and with the presence of ACPA. ${ }^{42}$

Our aim in the present study was to test the hypothesis that the PADI4 gene may similarly confer susceptibility to rheumatoid arthritis in a white French population. To do this, we analysed 100 white trio families composed of one affected subject and the two parents, using powerful and highly reliable family based association tests. Given the putative susceptibility haplotype frequency of $32 \%$ in patients and $25 \%$ in controls reported in the Japanese population, ${ }^{42}$ and assuming that the frequencies would be similar in our population, with our sample size we had a $93 \%$ power to observe an increased frequency of the putative haplotype in patients compared with controls, and a $46 \%$ power to observe a significant difference.

\section{METHODS}

\section{Patients and controls}

All subjects provided their informed consent, and the ethics committee of Hôpital Bicêtre (Kremlin-Bicêtre, France) approved the study.

Families with rheumatoid arthritis were recruited through a national media campaign followed by the selection of individuals who fulfilled the 1987 American College of Rheumatology (formerly the American Rheumatology Association) revised criteria for rheumatoid arthritis. ${ }^{4}$ All clinical data were reviewed by a rheumatologist. One hundred white French trio families composed of one affected subject and the two parents (with four white European grandparents) were investigated. Among the 100 rheumatoid patients, 87 were women and 13 were men; their mean age at disease onset was 39.6 years, $72 \%$ were RF positive, and $86 \%$ had erosive disease.

\section{DNA purification}

Genomic DNA was purified from peripheral blood mononuclear cells by standard methods.

\section{Primer design}

Primer pairs were designed using Primer 3 (web based version at http://www-genome.wi.mit.edu/cgi-bin/primer/ primer3_www.cgi), and then checked by Amplify 1.2 (Bill Engels, University of Wisconsin, Madison, Wisconsin, USA) and VectorNTI. Primer pairs obtained as described above and matching the PADI4 gene sequence only (verified by a blast search on the entire human genome) were synthesised and used for the amplification of the exons and SNP containing sequences.

\section{PCR-SSCP}

Polymerase chain reaction (PCR) amplifications were carried out on each sample in a $25 \mu \mathrm{l}$ reaction volume consisting of $10 \times$ PCR buffer (Perkin Elmer, Boston, Massachusetts, USA),
$0.5 \mu \mathrm{M}$ of each primer, $0.1 \mathrm{mM}$ of each dNTP, 1.25 units of TaqGold DNA polymerase (Perkin Elmer), $3 \mathrm{mM} \mathrm{MgCl}_{2}$, and $50 \mathrm{ng}$ of genomic DNA, diluted to the final volume with water. PCR amplification was done in a Mastercycler Gradient. After an initial denaturation step at $94^{\circ} \mathrm{C}$ for five minutes, the optimum number of cycles and temperatures were defined for each amplification product. The PCR products were run on $2 \%$ agarose IX TBE gel (Tris/borate/ EDTA buffer) to verify the size and the quality of the amplified DNA.

For the single strand conformational polymorphism (SSCP), the amplification products were mixed with an equal volume of formamide loading dye (95\% formamide, bromophenol blue-xylene cyanol 5\%) and subjected to electrophoresis under non-denaturing conditions on $12 \%$ polyacrylamide gels with $5 \%$ glycerol at $4^{\circ} \mathrm{C}$ for 15 to 20 hours in TBE $0.5 \times$ under a constant power of 5 watts. Single stranded DNA fragments in the gel were visualised by Syber Green staining (Tebu, France) under ultraviolet light.

The nucleotide sequence of the allelic variants defined by SSCP was confirmed by direct sequencing. Fluorescence based automated cycle sequencing of the PCR products was undertaken using an ABI DNA sequencer (PE Applied Biosystems, Foster City, California, USA).

\section{PCR-RFLP}

All the SNPs (RS188 1, RS188 2, PADI4 92, PADI4 96, and PADI4_102) are located in the contig NT_030584.10 (positions 456724, 456806, 484839, 487146, and 498564, respectively). Restriction fragment length polymorphism (RFLP) genotyping was carried out in the 100 rheumatoid families. We used the following primers for the PCR (forward and reverse, both $5^{\prime} \rightarrow 3^{\prime}$ ): RS188_1 GTGTGGCTGAAATGCAGTG AGGTA and CTCCAGGCTCCCCACGTTACTT; RSI88_2 GGGT CCCCTACAGTCTGTTCT and CCAGTGCAATCGGTACAAAG; PADI4_92 CCCAACTTTGTCTCCCCAGT and CGAGGTCCACA TCAAAGGAGATG; PADI4_96 AAACGACCTGCCCATTC and GGAAATACATAAGCCAAAATT; PADI4_102 CTGGCCCAGGCA CCACCAG and AGGGTTTCGGCAGCTGTGCC.

The restriction enzymes used were RsaI, NlaIII, MspI, HaeIII, and RsaI, respectively.

\section{Serological characterisation of the rheumatoid patients}

ACPA were detected by a commercially available assay based on cyclic citrullinated peptides (CCP) (QUANTA Lite ${ }^{\mathrm{TM}}$, CCP2, Inova Diagnostic, San Diego, California, USA) and by an enzyme linked immunosorbent assay (ELISA) recently developed in house, based on in vitro deiminated human fibrinogen (AhFibA, anti-human fibrin(ogen) autoantibodies). ${ }^{2}$ Sera were considered positive for anti-CCP antibodies when the level was higher than $20 \mathrm{U}$ (specificity >95\%). Sera were considered positive for AhFibA using a cut off allowing a specificity higher than $98.6 \%$.

\section{Statistical analysis}

The single locus association analysis of the PADI4 gene was carried out by means of the transmission disequilibrium test (TDT), implemented in the Genehunter 2 program. ${ }^{43}$ TDT compares the transmission of the SNP alleles from heterozygous parents to affected offspring with Mendel's expectation $(50 \%)$ using a bilateral $\chi^{2}$ test with one degree of freedom.

Genotype relative risk (GRR) was calculated using the Lathrop method..$^{44}$ GRR compares the differences in genotype distribution between rheumatoid patients and controls; controls are reconstructed genotypes from non-transmitted parental alleles. The Hardy-Weinberg equilibrium of each 
Table 1 Analysis of the single nucleotide polymorphisms: comparison of the frequency of transmitted and non-transmitted alleles, TDT, and GRR tests

\begin{tabular}{|c|c|c|c|c|c|c|c|}
\hline \multirow[b]{2}{*}{ SNP allele } & \multicolumn{3}{|c|}{ Allele frequencies } & \multicolumn{3}{|l|}{ TDT } & \multirow{2}{*}{$\begin{array}{l}\text { GRR } \\
p \text { Value }\end{array}$} \\
\hline & Freq transm & Freq untransm & p Value & Transm & Untransm & p Value & \\
\hline \multicolumn{8}{|c|}{ (A) In 100 RA families } \\
\hline RS188_1C & 0.545 & 0.530 & & 53 & 50 & 0.77 & \multirow{2}{*}{0.24} \\
\hline RS188_1T & 0.455 & 0.470 & 0.16 & 50 & 53 & 0.77 & \\
\hline RS188_2C & 0.800 & 0.865 & & 21 & 34 & 0.08 & \multirow{2}{*}{0.22} \\
\hline RS188_2G & 0.200 & 0.135 & 0.08 & 34 & 21 & 0.08 & \\
\hline PADI4_92C & 0.620 & 0.580 & & 51 & 43 & 0.41 & \multirow{2}{*}{0.63} \\
\hline PADI4_92G & 0.380 & 0.420 & 0.41 & 43 & 51 & 0.41 & \\
\hline PADI4_96C & 0.321 & 0.347 & & 39 & 44 & 0.58 & \multirow{2}{*}{0.52} \\
\hline PADI4_96T & 0.679 & 0.653 & 0.59 & 44 & 39 & 0.58 & \\
\hline PADI4_102T & 0.076 & 0.081 & & 14 & 15 & 0.85 & \multirow{2}{*}{0.60} \\
\hline PADI4_102C & 0.924 & 0.919 & 0.85 & 15 & 14 & 0.85 & \\
\hline \multicolumn{8}{|c|}{ (B) In families with anti-CCP ${ }^{+}$RA cases } \\
\hline RS188_1C & 0.556 & 0.535 & & 36 & 33 & 0.72 & \multirow{2}{*}{0.44} \\
\hline RS188_1T & 0.444 & 0.465 & 0.72 & 33 & 36 & 0.72 & \\
\hline RS188_2C & 0.831 & 0.845 & & 18 & 20 & 0.75 & \multirow{2}{*}{0.67} \\
\hline RS188_2G & 0.169 & 0.155 & 0.74 & 20 & 18 & 0.75 & \\
\hline PADI4_92C & 0.620 & 0.585 & & 38 & 33 & 0.55 & \multirow{2}{*}{0.08} \\
\hline PADI4_92G & 0.380 & 0.415 & 0.54 & 33 & 38 & 0.55 & \\
\hline PADI4_96C & 0.326 & 0.341 & & 30 & 32 & 0.80 & \multirow{2}{*}{0.69} \\
\hline PADI4_96T & 0.674 & 0.659 & 0.80 & 32 & 30 & 0.80 & \\
\hline PADI4_102T & 0.064 & 0.079 & & 8 & 10 & 0.64 & \multirow{2}{*}{0.59} \\
\hline PADI4_102C & 0.936 & 0.921 & 0.64 & 10 & 8 & 0.64 & \\
\hline \multicolumn{8}{|c|}{ (C) In families with AhFibA ${ }^{+}$RA cases } \\
\hline RS188_1C & 0.548 & 0.587 & & 29 & 34 & 0.53 & \multirow{2}{*}{0.57} \\
\hline RS188_1T & 0.452 & 0.413 & 0.52 & 34 & 29 & 0.53 & \\
\hline RS188_2C & 0.833 & 0.841 & & 17 & 18 & 0.87 & \multirow{2}{*}{0.89} \\
\hline RS188_2G & 0.167 & 0.159 & 0.86 & 18 & 17 & 0.87 & \\
\hline PADI4_92C & 0.611 & 0.563 & & 35 & 29 & 0.45 & \multirow{2}{*}{0.35} \\
\hline PADI4_92G & 0.389 & 0.437 & 0.44 & 29 & 35 & 0.45 & \\
\hline PADI4_96C & 0.336 & 0.344 & & 28 & 29 & 0.89 & \multirow{2}{*}{0.85} \\
\hline PADI4_96T & 0.664 & 0.656 & 0.89 & 29 & 28 & 0.89 & \\
\hline PADI4_102T & 0.073 & 0.073 & & 9 & 9 & 1 & \multirow{2}{*}{0.59} \\
\hline PADI4_102C & 0.927 & 0.927 & 1 & 9 & 9 & 1 & \\
\hline
\end{tabular}

SNP was investigated using a bilateral $\chi^{2}$ test with one degree of freedom.

Linkage disequilibrium was tested for each pair of markers by the Arlequin version 2 program. PADI4 haplotypes were inferred using the algorithm implemented in Genehunter2 ("haplo" option). The haplotype frequencies were estimated using the Arlequin version 2 program (Schneider S, Roessli D, Excoffier L. Arlequin: a software for population genetics data analysis, version 2.000. Genetics and Biometry, 2000).

\section{RESULTS}

To analyse the PADI4 haplotypes in the white French population, we selected three SNPs (PADI4_92, PADI4_96, and PADI4_102) that allowed us to describe the four haplotypes detected in the Japanese population.

We extended the analysis to the 5' region of the gene and carried out a preliminary SSCP study which detected an allelic variant. This was confirmed by direct sequencing which showed two SNPs located very close to one another: RS188_1 and RS188_2.

\section{Association study}

These five markers were typed by PCR-RFLP in the 100 rheumatoid patients and their parents. Each marker was in Hardy-Weinberg equilibrium in the control population (made up of non-transmitted parental chromosomes). The markers were not associated with the disease, nor were they preferentially transmitted by the TDT and GRR tests (table 1A). All the markers tested were in linkage disequilibrium.

\section{Haplotype analysis}

The analysis of the haplotypes showed that six of them had a frequency greater than $5 \%$ in our population. No haplotype was associated with the disease by any of the statistical tests used (table 2A).

Mapping the upstream SNPs RS188_1 and_2, we detected three haplotypes containing the one which conferred susceptibility to rheumatoid arthritis in Japanese patients (GCC haplotype, corresponding to haplotypes 3, 7, and 8 in table 2A). Only one of these had a frequency greater than $5 \%$.

Analysis of the haplotype frequency, haplotype transmission (table 2A) and GRR (table 3) for the group of GCC haplotypes did not show any difference between the control and patient populations.

Patients were then subgrouped according to the presence of ACPA detected by ELISA either onto cyclic citrullinated peptides (anti-CCP antibodies) or onto deiminated fibrinogen (AhFibA). The tests were positive in 71 and 63 patients, respectively, with $84 \%$ concordance between the tests. The SNPs were analysed in the CCP positive patients (table 1B) and the AhFibA positive patients (table $1 C$ ), and again no SNP was either associated with the disease or preferentially transmitted by the TDT and GRR tests.

No haplotype (including GCC haplotypes) was associated with the disease in these subgroups of patients (table 2B and 2C).

\section{DISCUSSION}

The results of the present study indicate that the PADI4 haplotype associated with rheumatoid arthritis in the 


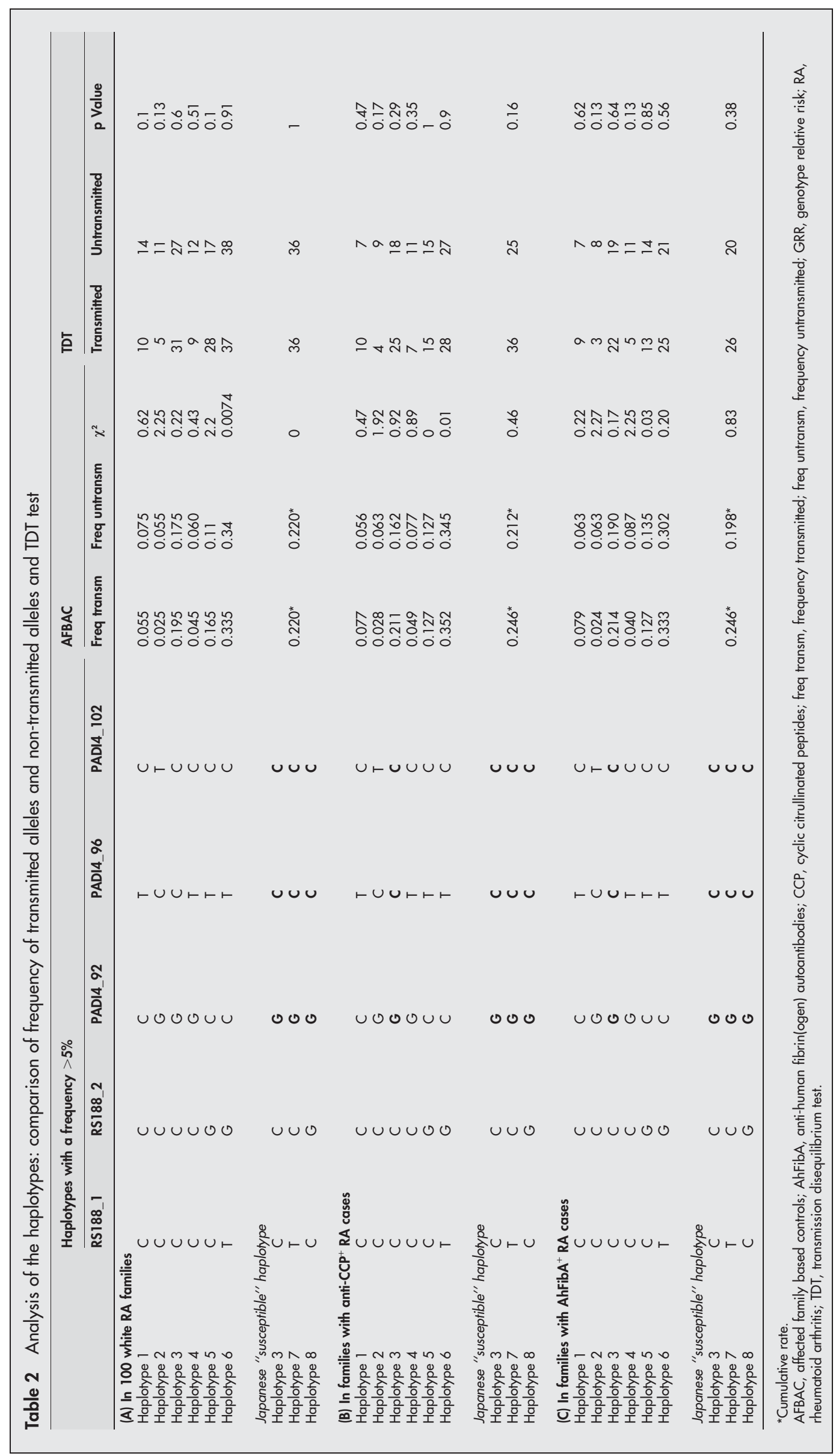


Table 3 Results of genotype relative risk test

\begin{tabular}{|c|c|c|c|c|c|c|c|c|c|}
\hline \multirow[b]{2}{*}{ Genotype } & \multicolumn{3}{|c|}{ In 100 white RA families } & \multicolumn{3}{|c|}{ In families with anti-CCP+ $R A$ cases } & \multicolumn{3}{|c|}{ In families with AhFibA ${ }^{+}$RA cases } \\
\hline & RA & Controls & $p$ Value & RA & Controls & $\mathrm{p}$ Value & RA & Controls & p Value \\
\hline NNGCC/NNGCC & 6 & 9 & & 6 & 7 & & 5 & 6 & \\
\hline $\mathrm{NNGCC} / \mathrm{X}$ & 31 & 21 & & 20 & 15 & & 18 & 12 & \\
\hline $\mathrm{X} / \mathrm{X}$ & 63 & 70 & 0.23 & 45 & 49 & 0.62 & 40 & 45 & 0.45 \\
\hline
\end{tabular}

Haplotypes 3,7 , and 8 have been pooled for analysis as they correspond to the haplotype (GCC) conferring susceptibility to rheumatoid arthritis in the Japanese population.

AhFibA, anti-human fibrin(ogen) autoantibodies; CCP, cyclic citrullinated peptides; RA, rheumatoid arthritis.

Japanese patients showed no such association in a white French population.

In the study carried out by Suzuki et al,,$^{42} 830$ patients and 736 controls were typed for 119 SNPs distributed along 445670 base pairs located in the contig NT_034376.1 on the chromosome 1p36. An SNP in the PADI4 gene (Padi4_94) showed a highly significant association with rheumatoid arthritis. Moreover, 17 SNPs were used to undertake a haplotype analysis of the PADI4 gene, and among the most frequently represented haplotypes one showed an association with rheumatoid arthritis.

On the basis of these results we carried out an analysis on 100 white French families composed of one affected subject and the two healthy parents. Three SNPs allowed us to describe the four haplotypes that are the most often represented in the Japanese population, including the one conferring susceptibility to the disease. These SNPs and others located in the upstream region of PADI4 were typed by RFLP. In our population, no SNP was significantly associated with rheumatoid arthritis.

The two haplotypes (CTC "non-susceptible" and GCC "susceptible") most often detected in the Japanese population (frequencies of 0.60 and 0.25 , respectively) were present in similar frequencies in our population (frequencies of 0.52 and 0.20). Despite its similar frequency, the haplotype associated with rheumatoid arthritis in the Japanese population was not associated with the disease in our white French population.

This negative result does not appear to reflect a lack of power, because we did not even observe a trend for an association of the susceptible haplotype (in the homozygous state) with rheumatoid arthritis. In fact, the frequency of this haplotype was lower in patients than in controls.

Similar negative results were recently reported by a group in the United Kingdom, who carried out a case-control study on 839 rheumatoid patients and 481 controls. ${ }^{45}$ The two haplotypes (CTC and GCC) were also highly represented in the white British subjects (frequencies of 0.59 and 0.39 , respectively). No association of rheumatoid arthritis with either a single SNP or haplotypes of the PADI4 gene was detected, even when the patients were stratified according to markers of disease severity or to the presence of the shared epitope.

Similarly, we did not find any evidence of association between the PADI4 gene and rheumatoid arthritis, even partitioning the patients according to RF positivity, shared epitope, or the presence of erosions (data not shown). Moreover, when patients were subgrouped according to the presence of ACPA, measured by two different methods, again no SNP or haplotype was associated with rheumatoid arthritis in ACPA positive patients.

The lack of replication of the Japanese findings in a white population could reflect differences in disease severity in the patient populations. However, similar positivity for rheumatoid factor was reported in all three studies.
Thus two independent studies of different experimental designs, a case-control study and a family based study, failed to detect any association between PADI4 and rheumatoid arthritis in north European white populations. It should be stressed that the use of family based association tests- that is, the transmission disequilibrium test and the haplotype relative risk-in the present study avoided the major drawback of imperfect matching of cases and controls. Given that no increased frequency of the putative haplotype was observed in patients versus controls, though we had a 93\% power to observe such a difference if it existed, our results are strongly against the putative hypothesis. In conjunction with the recently published observation from the UK group, ${ }^{45}$ we can conclude that a similar association is ruled out in white European populations. However, an association with other PADI4 alleles, especially alleles that would be relatively rare in the normal population, remains possible. Given these results, a replica study on Japanese patients would be of great interest.

Despite these negative results, PADI genes should still be considered potential candidate genes in rheumatoid arthritis. Indeed, the presence of ACPA exclusively in rheumatoid patients is striking, and PADs are the only enzymes responsible for the production of citrullinated proteins. The pathophysiological link between ACPA and rheumatoid arthritis is further strengthened by the observation that alleles of the shared epitope can present citrullinated peptides. In fact, Hill et a ${ }^{46}$ showed that the replacement of arginyl by citrullyl at the peptide side chain position interacting with the shared epitope significantly increases peptide-MHC affinity and leads to the activation of $\mathrm{CD}^{+} \mathrm{T}$ cells in HLA-DRB ${ }^{*} 0401$ transgenic mice. However, we found no evidence of an association between the PADI4 gene and rheumatoid arthritis, even when our patients were partitioned according to the shared epitope (data not shown).

The contribution of the genes encoding the other PAD isoforms should be more thoroughly investigated, as other susceptible regions containing PADI genes were identified by a refined genome-wide scan (DIS2644 and D1S478). Moreover, in the synovial tissue of rheumatoid patients, expression of not only PAD IV but also PAD II was recently demonstrated. ${ }^{47}$ The presence of PAD II mRNA has been detected in $\mathrm{CD}_{1} 4^{+}$cells from peripheral blood and synovial fluid, while the PAD II protein has been detected in significant amounts only in synovial fluid mononuclear cells. $^{39}$

Studies are in progress in our groups to evaluate the role of the genes encoding the other PAD isoforms. Other genetic factors such as those affecting tissue specific expression or enzyme activity of PADs may also contribute to the susceptibility to rheumatoid arthritis.

The identification of these genetic factors will aid in our understanding of why the immune response to citrullinated proteins occurs exclusively in rheumatoid arthritis. It will thus contribute to unravelling the pathophysiology of the disease. 


\section{ACKNOWLEDGEMENTS}

We thank the rheumatoid arthritis family members for their participation; for funding: Association Française des Polyarthritiques, Association de Recherche pour la Polyarthrite, Association Rhumatisme et Travail, Société Française de Rhumatologie, Génopole, Shering-Plough, Pfizer, Amgen, Conseil Régional Ile de France, Conseil Général de l'Essonne, Ministère de la Recherche et de l'Enseignement Supérieur and Fondation pour la Recherche Médicale, Institut National de la Santé et de la Recherche Médicale, and Centre National de la Recherche Scientifique (CNRS). We also thank Stéphane Chavanas for reading the manuscript and giving advice, and Leonor Nogueira for her participation in serological analyses with the efficient technical involvement of Marie-Françoise Isaça and Marie-Paule Henry.

\section{ECRAF MEMBERSHIP}

The European Consortium on Rheumatoid Arthritis Families, was initiated with funding from the European Commission (BIOMED2) by: T Bardin, D Charron, F Cornélis (coordinator), S Fauré, D Kuntz, M Martinez, J F Prudhomme, J Weissenbach (France); R Westhovens, J Dequeker (Belgium); A Balsa, D Pascuale-Salcedo (Spain); M Spyropoulou, C Stavropoulos (Greece); P Migliorini, S Bombardieri (Italy); P Barrera, L Van de Putte (Netherlands); H Alves, A Lopes-Vaz (Portugal).

\section{Authors' affiliations}

L Caponi, Department of Experimental Pathology, University of Pisa, Pisa, Italy

E Petit-Teixeira, C Pierlot, J Osorio, GenHotel, University Paris 7, EvryGenopole, France

M Sebbag, S Chapuy-Regaud, M Guerrin, G Serre, Unit of Epidermal Differentiation and Rheumatoid Autoimmunity, UMR 5165 CNRSToulouse III University, Toulouse, France

F Bongiorni, S Moscato, F Pratesi, P Migliorini, Clinical Immunology

Unit, Department of Internal Medicine, University of Pisa

F Cornelis, Clinical Genetics Unit, Hôpital Lariboisière, Assistance

Publique/Hôpitaux de Paris, Paris, France

\section{REFERENCES}

1 Schellekens GA, Visser H, de Jong BA, van den Hoogen FH, Hazes JM, Breedveld FC, et al. The diagnostic properties of rheumatoid arthritis antibodies recognizing a cyclic citrullinated peptide. Arthritis Rheum 2000;43:155-63.

2 Nogueira L, Sebbag M, Chapuy-Regaud S, Clavel C, Fournie B, Cantagrel A, et al. Autoantibodies to deiminated fibrinogen are the most efficient serological criterion for the diagnosis of rheumatoid arthritis [abstract]. Arthritis Res 2002:4(S1):A30.

3 Vincent C, Nogueira L, Sebbag M, Chapuy-Regaud S, Arnaud M, Letourneur $O$, et al. Detection of antibodies to deiminated recombinant rat filaggrin by enzyme-linked immunosorbent assay: a highly effective test for the diagnosis of rheumatoid arthritis. Arthritis Rheum 2002;46:2051-8.

4 Arnett FC, Edworthy SM, Bloch DA, McShane DJ, Fries JF, Cooper NS, et al. The American Rheumatism Association 1987 revised criteria for the classification of rheumatoid arthritis. Arthritis Rheum 1988;31:315-24.

5 Girbal E, Sebbag M, Gomes-Daudrix V, Simon M, Vincent C, Serre G. Characterisation of the rat oesophagus epithelium antigens defined by the socalled "antikeratin antibodies", specific for rheumatoid arthritis. Ann Rheum Dis 1993;52:749-57.

6 Simon M, Girbal E, Sebbag M, Gomes-Daudrix V, Vincent C, Salama G, et al. The cytokeratin filament-aggregating protein filaggrin is the target of the socalled "antikeratin antibodies," autoantibodies specific for rheumatoid arthritis. J Clin Invest 1993;92:1387-93.

7 Sebbag M, Simon M, Vincent C, Masson-Bessiere C, Girbal E, Durieux JJ, et al. The antiperinuclear factor and the so-called antikeratin antibodies are the same rheumatoid arthritis-specific autoantibodies. J Clin Invest 1995; $95: 2672-9$

8 Girbal-Neuhauser E, Durieux JJ, Arnaud M, Dalbon P, Sebbag M, Vincent C, et al. The epitopes targeted by the rheumatoid arthritis-associated antifilaggrin autoantibodies are post-translationally generated on various sites of (pro)filaggrin by deimination of arginine residues. J Immunol 1999; 162:585-94.

9 Schellekens GA, de Jong $B A$, van den Hoogen $F H$, van de Putte $L B$, van Venrooij WJ. Citrulline is an essential constituent of antigenic determinants recognized by rheumatoid arthritis-specific autoantibodies. J Clin Invest 1998;101:273-81.

10 Masson-Bessiere C, Sebbag M, Durieux JJ, Nogueira L, Vincent C, GirbalNeuhauser $\mathrm{E}$, et al. In the rheumatoid pannus, anti-filaggrin autoantibodies are produced by local plasma cells and constitute a higher proportion of $\lg G$ than in synovial fluid and serum. Clin Exp Immunol 2000;1 19:544-52.

11 Masson-Bessiere C, Sebbag M, Girbal-Neuhauser E, Nogueira L, Vincent C, Senshu T, et al. The major synovial targets of the rheumatoid arthritis-specific antifilaggrin autoantibodies are deiminated forms of the alpha- and betachains of fibrin. J Immunol 2001;166:4177-84.

12 Goldbach-Mansky R, Lee J, McCoy A, Hoxworth J, Yarboro C, Smolen JS, et al. Rheumatoid arthritis associated autoantibodies in patients with synovitis of recent onset. Arthritis Res 2000;2:236-43.

13 Paimela L, Palosuo T, Aho K, Lukka M, Kurki P, Leirisalo-Repo M, et al. Association of autoantibodies to filaggrin with an active disease in early rheumatoid arthritis. Ann Rheum Dis 2001;60:32-5.

14 van Gaalen FA, Linn-Rasker SP, van Venrooij WJ, de Jong BA, Breedveld FC, Verweij CL, et al. Autoantibodies to cyclic citrullinated peptides predict progression to rheumatoid arthritis in patients with undifferentiated arthritis: a prospective cohort study. Arthritis Rheum 2004;50:709-15.

15 Kurki P, Aho K, Palosuo T, Heliovaara M. Immunopathology of rheumatoid arthritis. Antikeratin antibodies precede the clinical disease. Arthritis Rheum 1992;35:914-17.

16 Berthelot JM, Maugars Y, Castagne A, Audrain M, Prost A. Antiperinuclear factors are present in polyarthritis before ACR criteria for rheumatoid arthritis are fulfilled. Ann Rheum Dis 1997;56:123-5.

17 Rantapaa-Dahlqvist S, de Jong BA, Berglin E, Hallmans G, Wadell G, Stenlund $\mathrm{H}$, et al. Antibodies against cyclic citrullinated peptide and $\lg A$ rheumatoid factor predict the development of rheumatoid arthritis. Arthritis Rheum 2003;48:2741-9.

18 Nielen MM, van Schaardenburg D, Reesink HW, van de Stadt RJ, van der Horst-Bruinsma IE, de Koning MH, et al. Specific autoantibodies precede the symptoms of rheumatoid arthritis: a study of serial measurements in blood donors. Arthritis Rheum 2004;50:380-6.

19 Bas S, Perneger TV, Mikhnevitch E, Seitz M, Tiercy JM, Roux-Lombard P, et al. Association of rheumatoid factors and anti-filaggrin antibodies with severity of erosions in rheumatoid arthritis. Rheumatology 2000;39:1082-8.

20 Kroot EJ, de Jong BA, van Leeuwen MA, Swinkels $H$, van den Hoogen FH, van't Hof $M$, et al. The prognostic value of anti-cyclic citrullinated peptide antibody in patients with recent-onset rheumatoid arthritis. Arthritis Rheum 2000;43:1831-5

21 Forslin K, Vincent C, Serre G, Svensson B. Antifilaggrin antibodies in early rheumatoid arthritis may predict radiological progression. Scand J Rheumatol $2001 ; 30: 221-4$.

22 Vencovsky J, Machacek S, Sedova L, Kafkova J, Gatterova J, Pesakova V, et al. Autoantibodies can be prognostic markers of an erosive disease in early rheumatoid arthritis. Ann Rheum Dis 2003;62:427-30.

23 Rus'd AA, Ikejiri Y, Ono H, Yonekawa T, Shiraiwa M, Kawada A, Takahara H. Molecular cloning of cDNAs of mouse peptidylarginine deiminase type I, type III and type IV, and the expression pattern of type I in mouse. Eur J Biochem 1999:259:660-9.

24 Ishigami A, Asaga H, Ohsawa T, Akiyama K, Maruyama N. Peptydilarginine deiminase type I, type II, type III and type IV, are expressed in rat epidermis. Biomed Res 2001;22:63-5.

25 Nishijyo T, Kawada A, Kanno T, Shiraiwa M, Takahara H. Isolation and molecular cloning of epidermal- and hair follicle-specific peptidylarginine deiminase (type III) from rat. J Biochem 1997; 121:868-75.

26 Yamakoshi A, Ono H, Nishijyo T, Shiraiwa M, Takahara H. Cloning of cDNA encoding a novel isoform (type IV) of peptidylarginine deiminase from rat epidermis. Biochim Biophys Acta 1998; 1386:227-32.

27 Watanabe K, Senshu T. Isolation and characterization of cDNA clones encoding rat skeletal muscle peptidylarginine deiminase. J Biol Chem 1989;264:15255-60.

28 Ishigami A, Kuramoto M, Yamada M, Watanabe K, Senshu T. Molecular cloning of two novel types of peptidylarginine deiminase CDNAs from retinoic acid-treated culture of newborn rat keratinocyte cell line. FEBS Lett 1998;433:113-18.

29 Wright PW, Bolling LC, Calvert ME, Sarmento OF, Berkeley EV, Shea MC, et al. $\mathrm{PAD}$, an oocyte and early embryo-abundant peptidylarginine deiminaselike protein that localizes to egg cytoplasmic sheets. Dev Biol 2003;256:73-88

30 Vossenaar ER, Zendman AJ, van Venrooij WJ, Pruijn GJ. PAD, a growing family of citrullinating enzymes: genes, features and involvement in disease. Bioessays 2003;25:1106-18.

31 Guerrin M, Ishigami A, Mechin MC, Nachat R, Valmary S, Sebbag M, et al. cDNA cloning, gene organization and expression analysis of human peptidylarginine deiminase type I. Biochem J 2003;370:167-74.

32 Ishigami A, Ohsawa T, Asaga H, Akiyama K, Kuramoto M, Maruyama N. Human peptidylarginine deiminase type II: molecular cloning, gene organization, and expression in human skin. Arch Biochem Biophys 2002;407:25-31.

33 Kanno T, Kawada A, Yamanouchi J, Yosida-Noro C, Yoshiki A, Shiraiwa M, et al. Human peptidylarginine deiminase type III: molecular cloning and nucleotide sequence of the cDNA, properties of the recombinant enzyme, and immunohistochemical localization in human skin. J Invest Dermatol 2000;115:813-23.

34 Nakashima K, Hagiwara T, Ishigami A, Nagata $S$, Asaga $H$, Kuramoto $M$, et al. Molecular characterization of peptidylarginine deiminase in $\mathrm{HL}-60$ cells induced by retinoic acid and lalpha,25-dihydroxyvitamin D(3). J Biol Chem 1999;274:27786-92

35 Chavanas S, Mechin MC, Takahara H, Kawada A, Nachat N, Serre G, et al. Comparative analysis of the mouse and human peptidylarginine deiminase gene (PADI) clusters reveals highly conserved non-coding segments and a new human gene, PADI6. Gene 2004;330:19-27.

36 Urano Y, Watanabe K, Sakaki A, Arase S, Watanabe Y, Shigemi F, Takeda K, Akiyama K, Senshu T. Immunohistochemical demonstration of peptidylarginine deiminase in human sweat glands. Am J Dermatopathol $1990 ; 12: 249-55$. 
37 Rogers G, Winter B, Mclaughlan C, Powell B, Nesci T. Peptidylarginine deiminase of the hair follicle: characterization, localization, and function in keratinizing tissues. J Invest Dermatol 1997;108:700-7.

38 Nakashima K, Hagiwara T, Yamada M. Nuclear localization of peptidylarginine deiminase $\mathrm{V}$ and histone deimination in granulocytes. J Biol Chem 2002;277:49562-8.

39 Vossenaar ER, Radstake TR, van der Heijden A, van Mansum MA, Dieteren C, de Rooij DJ, et al. Expression and activity of citrullinating peptidylarginine deiminase enzymes in monocytes and macrophages. Ann Rheum Dis 2004;63:373-81.

40 Cornelis F, Faure S, Martinez M, Prud'homme JF, Fritz P, Dib Cet, et al. New susceptibility locus for rheumatoid arthritis suggested by a genome-wide linkage study. Proc Natl Acad Sci USA 1998;95:10746-50.

41 Osorio Y, Fortea J, Bukulmez H, Petit-Teixeira E, Michou L, Pierlot C, et al. Dense genome-wide linkage analysis of rheumatoid arthritis including covariates. Arthritis Rheum 2004;50:2757-65.

42 Suzuki A, Yamada R, Chang X, Tokuhiro S, Sawada T, Suzuki M, et al. Functional haplotypes of PADI4, encoding citrullinating enzyme peptidylarginine deiminase 4 , are associated with rheumatoid arthritis. Nat Genet 2003;34:395-402.

43 Kruglyak L, Lander ES. Faster multipoint linkage analysis using Fourier transform. J Biol Spring 1998;5:1-7.

44 Lathrop GM. Estimating genotype relative risks. Tissue Antigens 1983;22:160-6.

45 Barton A, Bowes J, Eyre S, Spreckley K, Hinks A, John S, et al. Functional haplotype of the PADI4 gene associated with rheumatoid arthritis in a Japanese population is not associated in a United Kingdom. Arthritis Rheum 2004;50:1117-21

46 Hill JA, Southwood S, Sette A, Jevnikar AM, Bell DA, Cairns E. Cutting edge: the conversion of arginine to citrulline allows for a high-affinity peptide interaction with the rheumatoid arthritis-associated HLA-DRB1* $0401 \mathrm{MCH}$ class II molecule. J Immunol 2003;171:538-41.

47 Chapuy-Regaud S, Sebbag M, Nachat R, Baeten D, Foulquier V, Simon M, et al. Peptidylarginine deiminase isoforms expressed in the synovial membrane of rheumatoid arthritis patients [abstract]. Arthritis Res 2003;5:A5 